Fievez V, Vlaeminck B, Dhanoa MS \& Dewhurst RJ 2003 Use of principal component analysis to investigate the origin of heptadecenoic and conjugated linoleic acids in milk. Journal of Dairy Science 86 4047-4053

Garnsworthy PC, Masson LL, Lock AL \& Mottram TT 2006 Variation of milk citrate with stage of lactation and de novo fatty acid synthesis in dairy cows. Journal of Dairy Science 89 1604-1612

Gilmour AR, Gogel BJ, Cullis BR, Welham SJ \& Thompson R 2002 ASRem/ User Guide Release 1.0. Hemel Hempstead, UK: VSN International Ltd

Heck JML, van Valenberg HJF, Dijkstra J \& van Hooijdonk ACM 2009 Seasonal variation in the Dutch bovine raw milk composition. Journal of Dairy Science 92 4745-4755

Jacobs AAA, Van Baal J, Smits MA, Taweel HZH, Hendriks WH, van Vuuren AM \& Dijkstra J 2011 Effects of feeding rapeseed oil, soybean oil or linseed oil on stearoyl-coa desaturase expression in the mammary gland of dairy cows. Journal of Dairy Science 94 874-887

Jenkins TC, Wallace RJ, Moate PJ \& Mosley EE 2008 Recent advances in biohydrogenation of unsaturated fatty acids within the rumen microbial ecosystem. Journal of Animal Science 86 397-412

Jensen RG 2002 The composition of bovine milk lipids: January 1995 to December 2000. Journal of Dairy Science 85 295-350

Kliem KE, Morgan R, Humphries DJ, Shingfield KJ \& Givens DI 2008 Effect of replacing grass silage with maize silage in the diet on bovine milk fatty acid composition. Animal 2 1850-1880

Leonard AE, Pereira SL, Sprecher H \& Huang YS 2004 Elongation of longchain fatty acids. Progress in Lipid Research 43 36-54

Loor JJ, Ferlay A, Ollier A, Doreau M \& Chilliard Y 2005 Relationship among trans and conjugated fatty acids and bovine milk fat yield due to dietary concentrate and linseed oil. Journal of Dairy Science 88 726-740

Luna P, Rodriguez-Pino V \& de la Fuente MA 2009 Occurrence of C16:1 isomers in milk fats from ewes fed with different dietary lipid supplements. Food Chemistry 117 248-253

Massart-Leën AM \& Massart DL 1981 The use of clustering techniques in the elucidation or confirmation of metabolic pathways. Biochemical Journal $196611-618$

Massart-Leën AM, Roets E, Peeters G \& Verbeke R 1983 Propionate for fatty acid synthesis by the mammary gland of the lactating goat. Journal of Dairy Science 66 1445-1454

Mensink RP, Zock PL, Kester ADM \& Katan MB 2003 Effects of dietary fatty acids and carbohydrates on the ratio of serum total to HDL cholesterol and on serum lipids and apolipoproteins: a meta-analysis of 60 controlled trials. American Journal of Clinical Nutrition 77 1146-1155

Moate PJ, Chalupa W, Boston RC \& Lean IJ 2007 Milk fatty acids I: variation in the concentration of individual fatty acids in bovine milk. Journal of Dairy Science 90 4730-4739
Moate PJ, Chalupa W, Boston RC \& Lean IJ 2008 Milk fatty acids II: prediction of the production of individual fatty acids in bovine milk. Journal of Dairy Science 91 1175-1188

Odongo NE, Or-Rashid MM, Kebreab E, France J \& McBride BW 2007 Effect of supplementing myristic acid in dairy cow rations on ruminal methanogenesis and fatty acid profile in milk. Journal of Dairy Science 90 1851-1858

Rutten MJM, Bovenhuis $H$, Hettinga KA, van Valenberg HJF \& van Arendonk JAM 2009 Predicting bovine milk fat composition using infrared spectroscopy based on milk samples collected in winter and summer. Journal of Dairy Science 92 6202-6209

Schennink A, Stoop WM, Visker M, Heck JML, Bovenhuis H, van der Poel JJ, van Valenberg HJF \& van Arendonk JAM 2007 DGAT1 underlies large genetic variation in milk-fat composition of dairy cows. Animal Genetics 38 467-473

Schennink A, Heck JML, Bovenhuis H, Visker M, van Valenberg HJF \& van Arendonk JAM 2008 Milk fatty acid unsaturation: genetic parameters and effects of stearoyl-CoA desaturase (SCD1) and acyl CoA: diacylglycerol acyltransferase 1 (DGAT1). Journal of Dairy Science 91 2135-2143

Shingfield KJ, Reynolds CK, Lupoli B, Toivonen V, Yurawecz MP, Delmonte P, Griinari JM, Grandison AS \& Beever DE 2005 Effect of forage type and proportion of concentrate in the diet on milk fatty acid composition in cows given sunflower oil and fish oil. Animal Science 80 225-238

Stoop WM, van Arendonk JAM, Heck JML, van Valenberg HJF \& Bovenhuis H 2008 Genetic parameters for major milk fatty acids and milk production traits of Dutch Holstein-Friesians. Journal of Dairy Science 91 385-394

Stoop WM, Bovenhuis H, Heck JML \& van Arendonk JAM 2009 Effect of lactation stage and energy status on milk fat composition of HolsteinFriesian cows. Journal of Dairy Science 92 1469-1478

Van Bruggen C 2007 Dierlijke mest en mineralen 2005. Voorburg/Heerlen: Centraal Bureau voor de Statistiek

Van Zijderveld SM, Fonken B, Dijkstra J, Gerrits WJJ, Perdok HB, Fokkink W \& Newbold JR 2011 Effects of a combination of feed additives on methane production, diet digestibility and animal performance in lactating cows. Journal of Dairy Science 94 1445-1454

Vlaeminck B, Fievez V, Cabrita ARJ, Fonseca AJM \& Dewhurst RJ 2006 Factors affecting odd- and branched-chain fatty acids in milk: a review. Animal Feed Science and Technology 131 389-417

Walstra P, Wouters JTM \& Geurts TJ 2006 Dairy Science and Technology, 2nd edition. Taylor \& Francis, CRC Press, London

Wilmink JBM 1987 Adjustment of test-day milk, fat and protein yield for age, season and stage of lactation. Livestock Production Science 16 335-348

\title{
CORRIGENDUM
}

\section{Characterization of milk fatty acids based on genetic and herd parameters - CORRIGENDUM}

\author{
Jeroen ML Heck, Heim JF van Valenberg, Henk Bovenhuis, Jan Dijkstra and Toon CM van Hooijdonk \\ doi:10.1017/S0022029911000641, Published online by Cambridge University Press, 14 October 2011.
}

In the article by Heck et al. (2012) the name of the corresponding author is Dr Hein JF van Valenberg and not Heim as originally published. We apologise for this error.

\section{Reference}

Heck JML, van Valenberg HJF, Bovenhuis H, Dijkstra J \& van Hooijdonk TCM 2012 Journal of Dairy Research $7939-46$. 